\title{
GOSPODARSTWA ŁAૃCZĄCE EKOLOGICZNE I KONWENCJONALNE METODY PRODUKCJI NA TLE EKOLOGICZNYCH
}

\begin{abstract}
Abstrakt
Rolnictwo ekologiczne w Polsce obejmuje gospodarstwa stosujace wyłacznie ekologiczne metody produkcji oraz takie, w których współistnieje system ekologiczny i konwencjonalny. W danych statystycznych sa one ujmowane łacznie jako gospodarstwa ekologiczne.

Zaburza to prawdziwy obraz polskiego rolnictwa ekologicznego, zwłaszcza średnia powierzchnię obszarowa gospodarstwa, sytuacje produkcyjnoekonomiczna. Potwierdzaja to dane z gospodarstw ekologicznych prowadzacych rachunkowość w systemie Polski FADN. Między analizowanymi gospodarstwami ekologicznymi a „mieszanymi” istniały znaczne różnice $w$ strukturze upraw i pogłowiu zwierzat, poziomie ponoszonych kosztów i efektywności produkcji, a tym samym w ich dochodowości. Wyniki analizy dowiodty, że gospodarstwa mieszane byty dość konkurencyjne ekonomicznie w stosunku do gospodarstw stosujacych wyłacznie ekologiczny system produkcji, a ich dochód w znacznie mniejszym stopniu zależat od wsparcia zewnętrznego, choć poziom dopłat do działalności operacyjnej na 1 ha użytków rolnych byt zbliżony do poziomu w gospodarstwach ekologicznych.
\end{abstract}

Słowa kluczowe: rolnictwo ekologiczne, ekologiczny i konwencjonalny system produkcji, rachunkowość rolna, efektywność produkcji ekologicznej, dochodowość gospodarstw ekologicznych

\section{Wprowadzenie}

Rolnictwo ekologiczne funkcjonuje w Unii Europejskiej w oparciu o szereg przepisów prawnych, obowiązujących wszystkie kraje członkowskie UE. Zasadniczym aktem prawodawczym wyznaczającym kryteria prowadzenia ekologicz- 
nej produkcji rolniczej jest Rozporządzenie Rady (WE) nr 834/2007'. W preambule podkreśla ono podwójną funkcję rolnictwa ekologicznego - wytwarzania produktów na rynek oraz działania na rzecz ochrony środowiska przyrodniczego. Ze względu na funkcje prośrodowiskowe, Wspólna Polityka Rolna uruchomiła instrumenty finansowe mające wspierać rolnictwo ekologiczne - do rolników podejmujących się realizacji programu rolnośrodowiskowego skierowano dopłaty do produkcji ekologicznej. Zaktywizowało to rolników do przekształcania gospodarstw konwencjonalnych na ekologiczny system produkcji. Po przystąpieniu Polski do Unii Europejskiej również w naszym kraju znacznie zwiększyła się liczba gospodarstw ekologicznych i powierzchni użytków rolnych prowadzonych w systemie ekologicznym, podobnie jak wcześniej w innych krajach członkowskich. Tempo przyrostu wytwarzanych surowców i produktów ekologicznych w Polsce jest jednak znacznie powolniejsze, a przyczyn jest wiele.

Niedostateczny wolumen rynkowej produkcji ekologicznej jest spowodowany, między innymi, niewłaściwym sposobem organizacji produkcji. Przykładem są większe gospodarstwa, których celem jest często pozyskanie dotacji, a nie chęć trwałego rozwoju w systemie ekologicznym. Jednostki takie posiadają większą powierzchnię paszową, ale jednocześnie niską obsadę zwierząt lub rezygnują w ogóle $\mathrm{z}$ chowu zwierząt, wolniej też zwiększają powierzchnie upraw rolniczych w porównaniu do ogólnej powierzchni użytków rolnych (Kuś J., 2010). Znaczny odsetek polskich gospodarstw ekologicznych stanowią gospodarstwa nietowarowe lub o niskiej towarowości produkcji (Brodzińska K., 2014). Z przeglądu danych rachunkowych Polskiego FADN ${ }^{2}$ wynika, że do niskiej towarowości rolnictwa ekologicznego przyczynia się także funkcjonowanie gospodarstw mieszanych, czyli stosujących w jednym gospodarstwie zarówno ekologiczne, jak i konwencjonalne metody produkcji. Rozporządzenie Rady (WE) nr 834/2007 w obecnym kształcie dopuszcza współistnienie dwóch systemów produkcji w jednym gospodarstwie. W takiej sytuacji rolnik zobowiązuje się do przestrzegania określonych prawem zasad ich koegzystencji, które dyktuje artykuł 11 cytowanego wyżej rozporządzenia. Należy wówczas oddzielić ziemię, zwierzęta i środki używane do produkcji ekologicznej oraz produkty wytwarzane metodami ekologicznymi od wykorzystywanych i wytwarzanych nieekologicznie, prowadząc przy tym odpowiednią dokumentację.

Współistnienie systemu ekologicznego i konwencjonalnego (w dalszej części nazywanego mieszanym) w jednym gospodarstwie wywołuje jednak liczne kontrowersje, nasuwa wątpliwości co do warunków i jakości wytwarzanych produktów ekologicznych, zachowania różnorodności biologicznej, a także celowości kierowania dopłat ekologicznych do takich jednostek. To wsparcie po-

\footnotetext{
${ }^{1}$ Rozporządzenie Rady (WE) nr 834/2007 z dnia 28 czerwca 2007 r. w sprawie produkcji ekologicznej i znakowania produktów ekologicznych (Dz.Urz. UE L 189 z 20.07.2007, z późn. zm.).

${ }^{2}$ System Zbierania i Wykorzystywania Danych Rachunkowych z Gospodarstw Rolnych.
} 
winno być silnie związane z efektem produkcyjnym rolnictwa ekologicznego, gdyż sposób produkcji żywności ekologicznej oddziaływuje pozytywnie na środowisko automatycznie, w wyniku stosowania obowiązujących reguł produkcji. Dlatego przede wszystkim wytwarzanie żywności ekologicznej należy premiować systemem dopłat i zachęt (Jasiński J., Michalska S., Spiewak R., 2014), w związku ze zmniejszeniem wydajności produkcji na skutek eliminacji środków chemii syntetycznej. Szczególnie wskazane jest wspieranie gospodarstw ekologicznych z udziałem zwierząt (Nachtman G., 2014; Brodzińska K., 2009), a w przypadku produkcji roślinnej takich jednostek, które zwiększają dostępność żywności, a nie tylko powierzchni upraw (Brodzińska K., 2009). Trzeba mieć na uwadze, że zasoby ziemi rolniczej przede wszystkim powinny być wykorzystywane do produkcji surowców żywnościowych. Z perspektywy społeczeństwa gwarancja odpowiedniej ilości i jakości żywności jest podstawowym parametrem oceny sprawności rolnictwa (Floriańczyk Z., Buks J., 2012).

Prowadzenie produkcji w dwóch systemach w jednym gospodarstwie może utrudniać również kontrolowanie procesu produkcji, który jest konieczny dla uzyskania certyfikatu produktu ekologicznego. Na ten aspekt zwrócono uwagę w dokumencie Programu Rozwoju Obszarów Wiejskich na lata 2014-2020 (PROW 2014-2020) - zaakcentowano problem kontroli procesu produkcji ekologicznej. O ułomności łączenia tych dwóch systemów produkcji wypowiedziało się też wielu respondentów biorących udział w konsultacjach społecznych na temat sektora rolnictwa ekologicznego w pracach nad nowelizacją Rozporządzenia Rady (WE) 834/2007. W szczególności postulowane jest, aby całe gospodarstwo było prowadzone zgodnie z wymogami obowiązującymi dla produkcji ekologicznej. Potwierdza to cytat: „Uznaje się, że w gospodarstwach rolnych obejmujących jednostki, które nie są zarządzane zgodnie z regułami produkcji ekologicznej, zachodzi wyższe ryzyko nieprzestrzegania reguł produkcji ekologicznej. Dlatego też, po odpowiednim okresie konwersji, wszystkie gospodarstwa rolne w Unii, które zamierzają stać się gospodarstwami ekologicznymi, powinny być w całości zarządzane zgodnie $\mathrm{z}$ wymogami mającymi zastosowanie do produkcji eko-

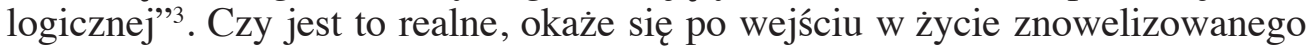
prawa, jako że oponenci tych zmian dostrzegają zahamowanie rozwoju rolnictwa ekologicznego, powrót wielu gospodarstw do systemu konwencjonalnego.

\section{Materiał badawczy i cel opracowania}

W Polsce dla wielu rolników korzystnie jest realizować produkcję w dwóch systemach, zwłaszcza gdy jakość gleb nie gwarantuje dobrych plonów w systemie rolnictwa konwencjonalnego. Stwarza to okazję do pozyskania dodatko-

\footnotetext{
${ }^{3}$ Wniosek. ROZPORZĄDZENIE PARLAMENTU EUROPEJSKIEGO I RADY w sprawie produkcji ekologicznej i znakowania produktów ekologicznych, zmieniające rozporządzenie Parlamentu Europejskiego i Rady (UE) nr XXX/XXX [rozporządzenie o kontrolach urzędowych] i uchylające rozporządzenie Rady (WE) nr 834/2007. Bruksela, dnia 24.3.2014 - http://www.minrol.gov.pl
} 
wych środków pieniężnych poprzez przestawienie części użytków rolnych na tory ekologiczne. Nie znamy liczby gospodarstw, w których koegzystuje produkcja ekologiczna i konwencjonalna, jednak wśród 27093 gospodarstw ekologicznych zarejestrowanych w publicznej bazie danych na koniec roku $2013^{4}$, pewną ich część stanowiły jednostki o dwóch systemach produkcji. Brak wzmianki na ten temat w statystyce publicznej prawdopodobnie utrudnia oszacowanie prawdziwego stanu produkcji rolnictwa ekologicznego w Polsce, zaburza wizerunek ekonomiczny gospodarstw ekologicznych, a zwłaszcza średnią powierzchnię obszarową gospodarstwa ekologicznego.

Liczne zastrzeżenia do współistnienia ekologicznego i konwencjonalnego systemu produkcji wskazują na sens rozpoznania sytuacji produkcyjno-ekonomicznej takich gospodarstw ${ }^{5}$, znaczenia dopłat, określenia ich pozycji w stosunku do gospodarstw w pełni ekologicznych, a co za tym idzie - ocenę zagrożeń dla rozwoju rolnictwa ekologicznego. Pomocne mogą być tu dane rachunkowe gospodarstw ekologicznych Polskiego FADN, które stanowią materiał badawczy tego opracowania.

Wyniki dla gospodarstw mieszanych prowadzących rachunkowość w Polskim FADN prezentowane są po raz pierwszy i stanowią swego rodzaju nowość (G. Nachtman, M. Puchalska, 2015). Od roku 2013 z bazy gospodarstw ekologicznych Polskiego FADN wydzielono dwie grupy: jedna to jednostki prowadzone w 100\% w systemie ekologicznym, a w drugiej jednostki, w których tylko część produkcji jest realizowana zgodnie z zasadami rolnictwa ekologicznego. Zestawienia liczbowe przedstawiono w postaci średnich arytmetycznych dotyczących roku 2013. Formuła gromadzonych danych w tym systemie nie pozwala na wyodrębnienie informacji odnośnie części ekologicznej i konwencjonalnej produkcji, opisy odnoszą się więc do całego gospodarstwa, a nie tylko do częśsi ekologicznej. Sytuację gospodarstw mieszanych prześledzono na tle gospodarstw stosujących wyłącznie ekologiczne metody produkcji, znajdujących się w bazie Polskiego FADN. Są to gospodarstwa certyfikowane. Materiał badawczy stanowi 113 gospodarstw mieszanych i 301 gospodarstw ekologicznych.

W celu zgłębienia istoty funkcjonowania gospodarstw analizę przeprowadzono w 4 grupach, wydzielonych według wielkości użytków rolnych i nazywanych następująco: „małe” (od 5 do <= 10 ha), ,średnio-małe” (od 10 do <= 20 ha), ,średnio-duże” (od 20 do <=30 ha, ,bardzo duże”( $>50$ ha). Dla grupy „duże” (od 30 do $<=50$ ha) przedstawiono dane tylko dla gospodarstw ekologicznych, gdyż mieszane były reprezentowane w liczbie mniejszej niż $15^{6}$; za mało było także gospodarstw w przedziale do 5 ha UR w obydwu systemach produkcji.

\footnotetext{
${ }^{4}$ Główny Inspektorat Jakości Handlowej Artykułów Rolno-Spożywczych.

${ }^{5}$ Dla uproszczenia, w dalszej części opracowania gospodarstwa z produkcją ekologiczną i konwencjonalną noszą nazwę „mieszanych”, a stosujące tylko metody ekologiczne - „ekologiczne”.

${ }^{6}$ Metodyka FADN wyklucza publikowanie średnich danych dla grupy liczącej mniej niż 15 gospodarstw.
} 


\section{Charakterystyka badanych gospodarstw}

Przegląd materiałów źródłowych gospodarstw mieszanych w bazie Polskiego FADN pozwala wnioskować, że ograniczały one, na przykład, liczbę upraw w części ekologicznej i pogłowie zwierząt. Jednocześnie, z uwagi na intensywniejszy charakter produkcji w segmencie konwencjonalnym, ich kondycja ekonomiczna była lepsza niż gospodarstw stosujących wyłącznie ekologiczny system produkcji. Gospodarstwa mieszane charakteryzowała duża różnorodność pod względem organizacji produkcji. Wśród nich były jednostki, w których prowadzono ekologiczne uprawy polowe czy sadownicze na całości użytków rolnych (UR), a wiodący kierunek produkcji stanowiła ferma drobiu lub trzody chlewnej w systemie konwencjonalnym. Występowały gospodarstwa specjalizujące się w uprawach polowych w systemie konwencjonalnym, w których tylko użytki zielone traktowano w sposób ekologiczny, przy jednoczesnym braku zwierząt $\mathrm{w}$ gospodarstwie. Miały też miejsce przypadki uprawy tych samych gatunków roślin, zarówno w systemie ekologicznym, jak i konwencjonalnym. Rozpoznanie rodzajów upraw, poziomu osiąganych plonów, wielkości i rodzaju czynionych nakładów środków produkcji, rodzaju zakupywanych środków produkcji i paszy dla zwierząt pozwala na powyższe wnioskowanie. Przypuszcza się, że uprawy ekologiczne podejmowano niejednokrotnie na gruntach gorszej jakości, zwłaszcza w dużych obszarowo gospodarstwach. Dowiodły tego już analizy gospodarstw ekologicznych Polskiego FADN (Nachtman G., 2013). Uprawa na użytkach rolnych słabszej jakości wymaga większych nakładów środków produkcji, które w przypadku rolnictwa ekologicznego mogą być zrekompensowane przez dopłaty ekologiczne. Ważną informacją jest również to, że wśród gospodarstw mieszanych ponad $1 / 4$ posiadała więcej niż 50 ha UR, podczas gdy wśród ekologicznych tylko 1/10 miała taki obszar (tab. 1).

\section{Omówienie wyników}

Organizacja produkcji. Średni obszar użytków rolnych w trzech najmniejszych grupach (od „małych” do ,średnio-dużych”) dla gospodarstw w obydwu systemach był bardzo zbliżony. W przedziale powyżej 50 ha gospodarstwa mieszane posiadały średnią powierzchnię o około $30 \%$ większą niż ekologiczne. Charakteryzował je też wyższy potencjał ekonomiczny, z wyjątkiem ,średniomałych", przy czym jednostki powyżej 50 ha UR miały wielkość ekonomiczną aż 2-krotnie wyższą niż ekologiczne. Na podstawie zgromadzonych danych w systemie FADN widoczny jest dość odmienny udział poszczególnych gałęzi produkcji (tab. 1, rys. 2). W użytkach rolnych, zarówno w gospodarstwach mieszanych jak i ekologicznych, największy udział miały uprawy pastewne, przy czym w grupach obszarowych do 30 ha w gospodarstwach mieszanych stanowiły one o około $9 \%$ mniej niż w ekologicznych, a w grupach powyżej 50 ha o około $6 \%$ mniej. W gospodarstwach mieszanych uprawy pastewne stanowiły najwięcej $(49,4 \%)$ w przedziale od 5 do 10 ha UR. Odwrotna sytuacja była 
w gospodarstwach ekologicznych: w przedziale UR od 5 do 10 ha uprawy pastewne miały najmniejszy udział $(40,2 \%)$, natomiast w pozostałych ich udział wzrastał i wynosił od około 50 do $60 \%$. Na drugiej pozycji w strukturze upraw były zboża - stanowiły od około 24 do $40 \%$ UR zarówno w gospodarstwach mieszanych, jak i ekologicznych (tabela 1) i, z wyjątkiem jednostek „małych”, ich udział był o około $8 \%$ wyższy w pozostałych grupach obszarowych gospodarstw mieszanych w porównaniu do ekologicznych.

Pozostałe uprawy polowe zajmowały od 4,5 do 12\% UR w gospodarstwach mieszanych, z tendencją rosnącą w miarę wzrostu obszaru gospodarstw. W gospodarstwach ekologicznych relacje były odwrotne - w największych obszarowo (powyżej 50 ha) uprawy polowe stanowiły najmniej (niespełna 4\%), a w mniejszych obszarowo grupach od 7,2 do $11,0 \%$. Gospodarstwa mieszane w porównaniu do ekologicznych wyróżniały się większym udziałem upraw sadowniczych we wszystkich przedziałach użytków rolnych. Aż 19,1\% powierzchni zajmowały one w gospodarstwach „małych”, a w dwóch kolejnych grupach obszarowych po około $11 \%$, zniżając się do wartości $4,6 \%$ w grupie „bardzo dużych”. W gospodarstwach ekologicznych najwyższy udział sadów $(12,5 \%)$ również cechował gospodarstwa „małe”, ale w pozostałych przedziałach wynosił od 2 do 5,9\% powierzchni użytków rolnych - tab. 1 .

Ważnym składnikiem upraw, zwłaszcza w gospodarstwach ekologicznych o obszarze do 20 ha, były warzywa. Zajmowały one w użytkach rolnych najwyżej 5\%, ale ich rola w przychodzie z produkcji była równie znacząca jak produkcja owoców uprawianych na szerszą skalę. W gospodarstwach mieszanych warzywa stanowiły najwięcej $(4,4 \%)$ w strukturze upraw w gospodarstwach ,średnio-dużych".

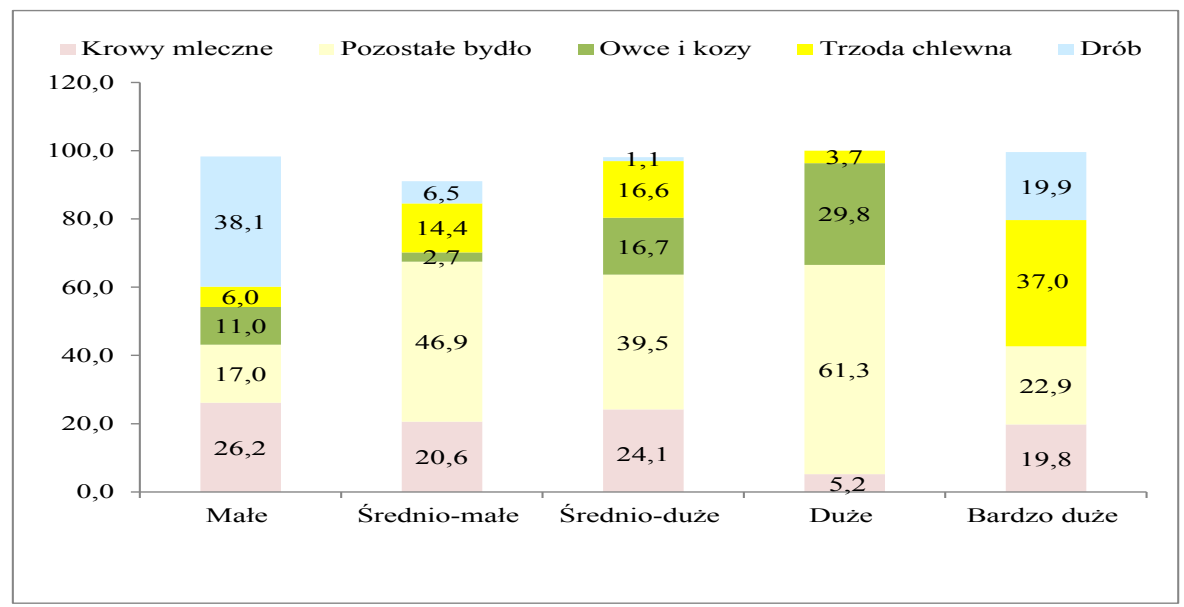

Rys. 1. Struktura procentowa pogłowia zwierząt - gospodarstwa mieszane Źródło: Obliczenia na podstawie danych Polskiego FADN. 
Tabela 1

Wielkość ekonomiczna i organizacja produkcji w gospodarstwach mieszanych i ekologicznych

\begin{tabular}{|c|c|c|c|c|c|}
\hline \multirow{2}{*}{ Rodzaj gospodarstw } & Małe & Średnio-małe & Średnio-duże & Duże & Bardzo duże \\
\hline & $5<\mathrm{ha} \leq 10$ & $10<\mathrm{ha} \leq 20$ & $20<\mathrm{ha} \leq 30$ & $30<\mathrm{ha} \leq 50$ & ha $>50$ \\
\hline \multicolumn{6}{|c|}{ Liczba gospodarstw } \\
\hline Mieszane & 15 & 26 & 28 & 13 & 29 \\
\hline Ekologiczne & 68 & 93 & 53 & 44 & 34 \\
\hline \multicolumn{6}{|c|}{ Wielkość ekonomiczna w tys. euro } \\
\hline Mieszane & 15135 & 16040 & 25222 & . & 118672 \\
\hline Ekologiczne & 11035 & 16264 & 19678 & 29884 & 64831 \\
\hline \multicolumn{6}{|c|}{ Powierzchnia użytków rolnych - ha } \\
\hline Mieszane & 7,6 & 15,0 & 23,8 & . & 137,4 \\
\hline Ekologiczne & 7,8 & 14,2 & 25,1 & 39,4 & 104,5 \\
\hline \multicolumn{6}{|c|}{ Udział użytków rolnych dodzierżawionych - \% } \\
\hline Mieszane & 15,5 & 14,0 & 19,9 & . & 24,2 \\
\hline Ekologiczne & 9,3 & 15,5 & 20,6 & 21,0 & 36,4 \\
\hline \multicolumn{6}{|c|}{ Udział zbóż w UR - \% } \\
\hline Mieszane & 23,5 & 37,8 & 32,1 & . & 39,2 \\
\hline Ekologiczne & 32,4 & 29,6 & 24,2 & 30,1 & 31,7 \\
\hline \multicolumn{6}{|c|}{ Udział pozostałych upraw polowych - \% } \\
\hline Mieszane & 4,5 & 8,4 & 10,5 & . & 11,9 \\
\hline Ekologiczne & 7,7 & 7,2 & 11,0 & 7,5 & 3,8 \\
\hline \multicolumn{6}{|c|}{ Udział warzyw w UR - \% } \\
\hline Mieszane & 1,8 & 1,9 & 4,4 & . & 0,1 \\
\hline Ekologiczne & 5,0 & 4,4 & 0,9 & 0,8 & 1,0 \\
\hline \multicolumn{6}{|c|}{ Udział sadów w UR - \% } \\
\hline Mieszane & 19,1 & 10,6 & 11,1 & . & 4,6 \\
\hline Ekologiczne & 12,5 & 5,9 & 2,0 & 4,6 & 3,1 \\
\hline \multicolumn{6}{|c|}{ Udział upraw pastewnych w UR - \% } \\
\hline Mieszane & 49,4 & 40,1 & 40,9 & . & 40,8 \\
\hline Ekologiczne & 40,2 & 50,4 & 59,9 & 54,7 & 56,5 \\
\hline \multicolumn{6}{|c|}{ Zwierzęta ogółem - LU } \\
\hline Mieszane & 10,9 & 8,2 & 9,7 & . & 62,6 \\
\hline Ekologiczne & 5,1 & 7,4 & 11,9 & 14,7 & 20,3 \\
\hline \multicolumn{6}{|c|}{ LU na 1 ha UR } \\
\hline Mieszane & 1,44 & 0,55 & 0,41 & . & 0,46 \\
\hline Ekologiczne & 0,65 & 0,52 & 0,47 & 0,37 & 0,19 \\
\hline \multicolumn{6}{|c|}{ LU na 1 ha powierzchni paszowej } \\
\hline Mieszane & 1,54 & 0,88 & 0,78 & . & 0,44 \\
\hline Ekologiczne & 1,19 & 0,83 & 0,65 & 0,49 & 0,26 \\
\hline
\end{tabular}

Źródło: Obliczenia na podstawie danych Polskiego FADN. 
Istotne różnice cechowały gospodarstwa pod względem pogłowia zwierząt; gospodarstwa mieszane posiadały ich więcej i wyższa była ich obsada na 1 ha UR, z wyjątkiem jednostek „średnio-dużych”. Szczególnie duże różnice widoczne były w gospodarstwach „małych” i „bardzo dużych”. Obsada zwierząt w podmiotach mieszanych była średnio około 2-krotnie wyższa niż w ekologicznych. Najwyższa obsada na 1 ha UR spośród wszystkich analizowanych grup była w gospodarstwach mieszanych ,małych" i wynosiła 1,44 LU7, w pozostałych grupach - od 0,55 do 0,41 LU (tab. 1). W gospodarstwach ekologicznych najwyższą obsadę miały również podmioty „małe” (0,65 LU/ha), zmniejszającą się ze wzrostem powierzchni obszarowej do poziomu 0,19 LU ha w gospodarstwach „,bardzo dużych”. Podobnie, w miarę wzrostu powierzchni UR malała obsada zwierząt na jednostkę powierzchni paszowej. W gospodarstwach ekologicznych obsada była nieco niższa niż w odpowiednich grupach gospodarstw mieszanych.

Pogłowie zwierząt charakteryzowało się, poza odmienną obsadą, znacznym zróżnicowaniem gatunkowym. Gospodarstwa mieszane o skrajnych wielkościach obszarowych (,małe” i „bardzo duże”) wyróżniały się dużym udziałem drobiu i trzody chlewnej: łącznie odpowiednio 44,1\% i 56,9\% stanu pogłowia (rys. 1). W gospodarstwach od 10 do 50 ha największy udział miało bydło łącznie od 63,6 do 67,5\% stanu zwierząt.

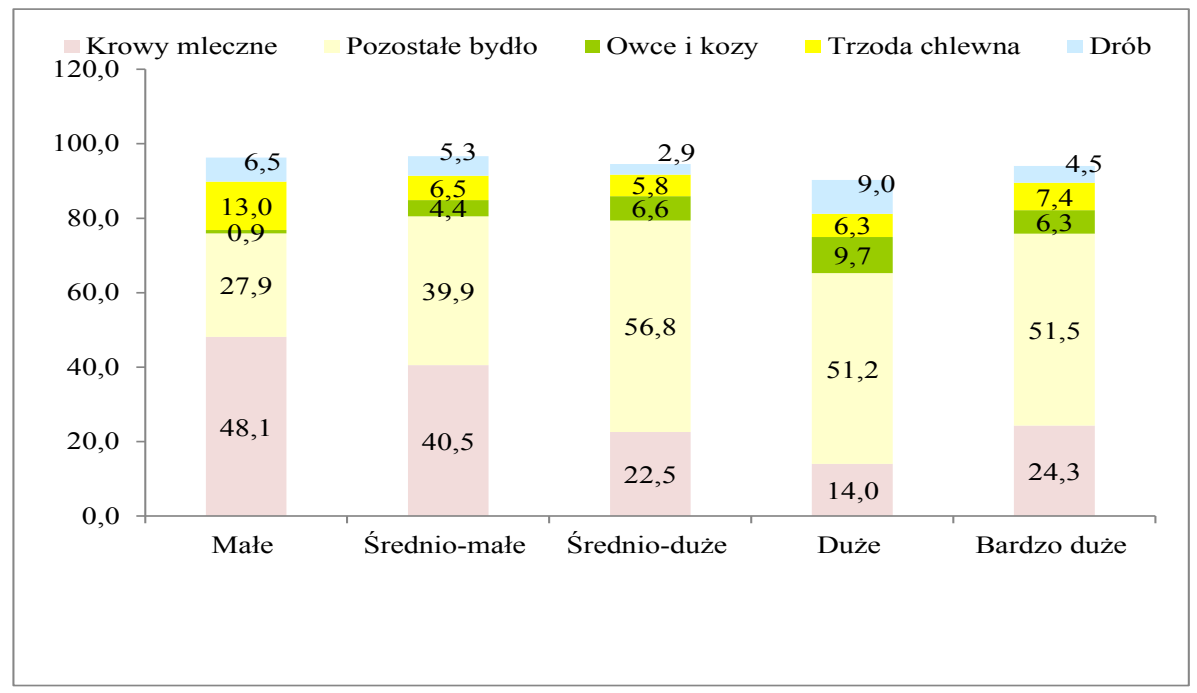

Rys. 2. Struktura procentowa pogłowia zwierząt - gospodarstwa ekologiczne Źródło: Obliczenia na podstawie danych Polskiego FADN.

${ }^{7}$ LU ang. Livestock Unit - jednostka przeliczeniowa zwierząt według metodyki FADN. 1 LU jest równoważna 1 krowie mlecznej albo 1 bykowi w wieku 2 lub więcej lat. Pozostałe zwierzęta stanowią odpowiednio część takiej jednostki przeliczeniowej, na przykład matka owcza $=0,1 \mathrm{LU}$, tucznik $=0,3 \mathrm{LU}$. 
W gospodarstwach ekologicznych chów trzody chlewnej i drobiu był mniej popularny i te gatunki łącznie stanowiły maksymalnie 19,5\% pogłowia (gospodarstwa „małe”). Dominowało natomiast bydło, przy czym w gospodarstwach mniejszych (do 20 ha UR) krowy mleczne, a w większych (powyżej 20 ha) bydło opasowe. Łącznie stanowiły one w poszczególnych grupach od około 65 do $80 \%$ stanu pogłowia.

Intensywność produkcji. W obydwu analizowanych rodzajach gospodarstw koszty prowadzenia działalności operacyjnej, podobnie jak organizacja produkcji, kształtowały się odmiennie, z widoczną przewagą intensywności produkcji w poszczególnych grupach obszarowych jednostek mieszanych (tab. 2). Jedynym wyjątkiem były gospodarstwa „średnio-małe” (10-20 ha UR), w których koszty ogółem na 1 ha, będące wskaźnikiem intensywności produkcji, były o 10\% niższe niż w gospodarstwach ekologicznych. Najwyższą intensywnością produkcji, zarówno w gospodarstwach mieszanych, jak i ekologicznych, odznaczała się grupa jednostek „małych”, w których koszty ogółem na 1 ha UR wynosiły odpowiednio 6342 i 4624 zł. Na te wysokie koszty składały się głównie koszty bezpośrednie, w tym pasz, koszty ogólnogospodarcze, ale też wysokie koszty opłaty pracy obcej i dzierżawy ziemi. W miarę wzrostu obszaru intensywność produkcji malała w obydwu rodzajach gospodarstw. W gospodarstwach mieszanych przyjmowała ona kolejno wartość: 3127 zł/ha (,średnio-małe”), 3815 zł/ha (,średnio-duże”) i 2858 zł/ha (,,bardzo duże”) - tab. 2. W gospodarstwach ekologicznych spadek kosztów był bardziej radykalny, bo z poziomu 3433 zł w gospodarstwach ,średnio-małych” do 1583 zł w „,bardzo dużych”. W grupie gospodarstw „bardzo dużych” odnotowano największą różnicę w poziomie intensywności produkcji między gospodarstwami mieszanymi a ekologicznymi. Koszty ogółem w jednostkach ekologicznych były niższe o $81 \%$, ale podobne proporcje zaistniały w efektywności produkcji.

Analiza poszczególnych składników kosztów ogółem wskazuje, że tendencję spadkową obserwowano w większości z nich w miarę wzrostu obszaru obydwu rodzajów gospodarstw. Wyjątkowo, w gospodarstwach mieszanych „bardzo dużych" koszty bezpośrednie (w tym nawozy, środki ochrony, pasze dla zwierząt ziarnożernych) były wyższe niż w gospodarstwach od 10 do 30 ha. Pewien wyjątek stanowiły też wśród wszystkich gospodarstw jednostki mieszane „średnio-duże”, w których poniesiono najwyższe koszty wynagrodzeń na 1 ha (649 zł). Warto zwrócić uwagę na bardzo niski poziom kosztów nawożenia (8-56 zł/ha) i środków ochrony roślin (1-21zł/ha) w gospodarstwach ekologicznych. W gospodarstwach mieszanych były one kilkakrotnie wyższe (115-292 zł/ha), ale także znacznie poniżej kwot dużo wyższych, wydatkowanych w gospodarstwach konwencjonalnych uczestniczących w Polskim FADN, w których ponadto zwiększały się ze wzrostem powierzchni gospodarstwa (G. Nachtman, M. Puchalska, 2015). 
Tabela 2

Koszty produkcji na 1 ha użytków rolnych w gospodarstwach mieszanych i ekologicznych

\begin{tabular}{|c|c|c|c|c|c|}
\hline \multirow{2}{*}{$\begin{array}{l}\text { Rodzaj } \\
\text { gospodarstw }\end{array}$} & Małe & Średnio-małe & Średnio-duże & Duże & Bardzo duże \\
\hline & $5<\mathrm{ha} \leq 10$ & $10<\mathrm{ha} \leq 20$ & $20<\mathrm{ha} \leq 30$ & $30<\mathrm{ha} \leq 50$ & ha $>50$ \\
\hline \multicolumn{6}{|c|}{ Koszty ogółem - zl/ha } \\
\hline Mieszane & 6342 & 3127 & 3815 & . & 2858 \\
\hline Ekologiczne & 4624 & 3433 & 2369 & 2007 & 1583 \\
\hline \multicolumn{6}{|c|}{ Koszty bezpośrednie - zl/ha } \\
\hline Mieszane & 3176 & 1143 & 1157 & . & 1451 \\
\hline Ekologiczne & 1220 & 926 & 659 & 511 & 431 \\
\hline \multicolumn{6}{|c|}{ w tym: } \\
\hline \multicolumn{6}{|c|}{ nawozy - zł/ha } \\
\hline Mieszane & 187 & 115 & 228 & . & 292 \\
\hline Ekologiczne & 52 & 36 & 8 & 18 & 56 \\
\hline \multicolumn{6}{|c|}{ środki ochrony - zł/ha } \\
\hline Mieszane & 54 & 33 & 81 & . & 141 \\
\hline Ekologiczne & 21 & 12 & 1 & 10 & 11 \\
\hline \multicolumn{6}{|c|}{ nasiona i sadzonki - zt/ha } \\
\hline Mieszane & 130 & 135 & 225 & . & 141 \\
\hline Ekologiczne & 160 & 142 & 92 & 106 & 87 \\
\hline \multicolumn{6}{|c|}{ pasze dla zwierząt trawożernych - zł/ha } \\
\hline Mieszane & 612 & 483 & 247 & . & 114 \\
\hline Ekologiczne & 459 & 423 & 350 & 181 & 141 \\
\hline \multicolumn{6}{|c|}{ pasze dla zwierząt ziarnożernych - zł/ha } \\
\hline Mieszane & 1895 & 224 & 165 & . & 653 \\
\hline Ekologiczne & 288 & 145 & 101 & 117 & 81 \\
\hline \multicolumn{6}{|c|}{ Koszty ogólnogospodarcze - zl/ha } \\
\hline Mieszane & 1343 & 965 & 976 & . & 628 \\
\hline Ekologiczne & 1584 & 1189 & 812 & 704 & 503 \\
\hline \multicolumn{6}{|c|}{ Koszty obcych czynników produkcji } \\
\hline Mieszane & 489 & 168 & 772 & . & 346 \\
\hline Ekologiczne & 376 & 305 & 147 & 190 & 234 \\
\hline \multicolumn{6}{|c|}{ Wynagrodzenia - zl/ha } \\
\hline Mieszane & 447 & 78 & 649 & . & 202 \\
\hline Ekologiczne & 318 & 215 & 68 & 94 & 99 \\
\hline \multicolumn{6}{|c|}{ Czynsze dzierżawne - zl/ha } \\
\hline Mieszane & 32 & 42 & 57 & 60 & 72 \\
\hline Ekologiczne & 20 & 32 & 35 & 44 & 99 \\
\hline \multicolumn{6}{|c|}{ Odsetki } \\
\hline Mieszane & 10 & 48 & 66 & & 73 \\
\hline Ekologiczne & 38 & 58 & 44 & 52 & 36 \\
\hline
\end{tabular}

Źródło: Obliczenia na podstawie danych Polskiego FADN. 


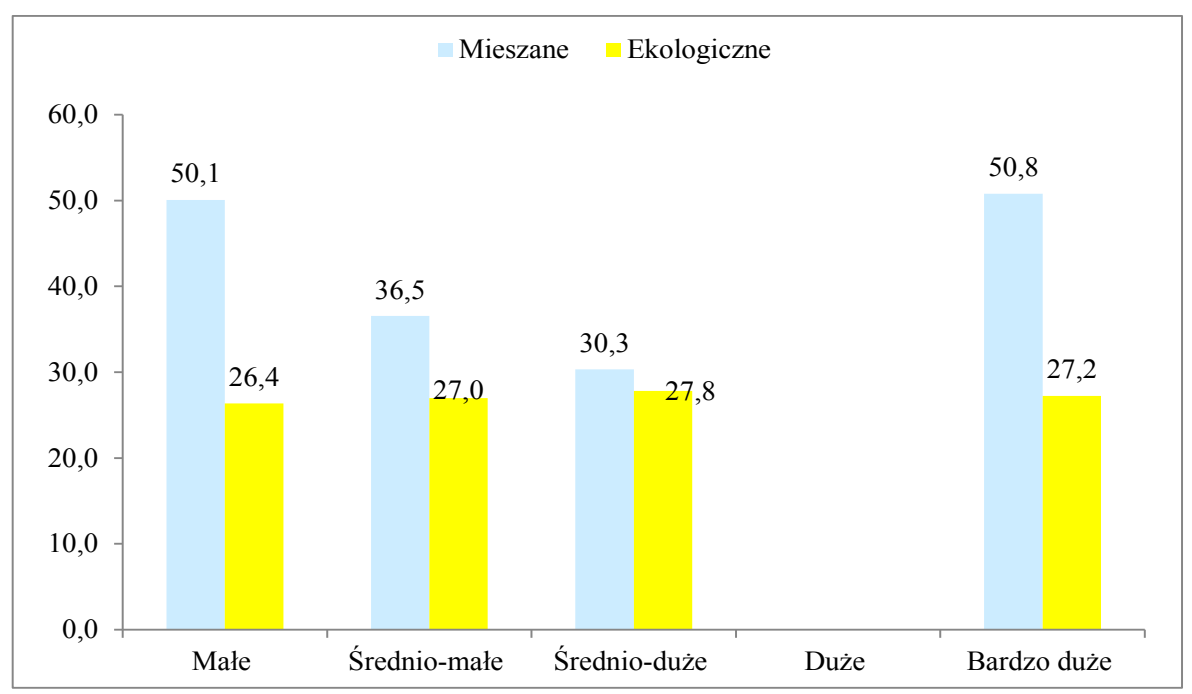

Rys. 3. Udział kosztów bezpośrednich w kosztach ogółem w gospodarstwach mieszanych i ekologicznych - \%

Źródło: Obliczenia na podstawie danych Polskiego FADN.

Efektywność produkcji determinują w największym stopniu poniesione nakłady bezpośrednich czynników produkcji, zobrazowane poziomem kosztów bezpośrednich. W podmiotach mieszanych „małych” i „bardzo dużych” obszarowo stanowiły one średnio około 50\% kosztów ogółem (rys. 3), w czym partycypowały koszty zakupu pasz. Jak pokazują wyniki rachunkowości Polskiego FADN, taki poziom kosztów bezpośrednich jest charakterystyczny dla gospodarstw nastawionych na produkcję drobiarską i chów trzody chlewnej. Dane źródłowe badanych gospodarstw świadczą o tym, że są to działalności realizowane w systemie konwencjonalnym - przemawia za tym rodzaj zakupywanych pasz treściwych, środków chemii rolnej i usług weterynaryjnych. W gospodarstwach mieszanych o obszarze od 10 do 30 ha koszty bezpośrednie wynosiły około 30-36\% wartości kosztów ogółem. Znacznie niższy był udział kosztów bezpośrednich w gospodarstwach ekologicznych; kształtowały się one na poziomie około $27 \%$ wartości kosztów ogółem (rys. 3), niezależnie od wielkości obszarowej gospodarstwa.

Struktura, poziom i efektywność produkcji. Przegląd struktury produkcji wskazuje na duże rozbieżności udziału produkcji roślinnej i zwierzęcej w produkcji ogółem, szczególnie w gospodarstwach mieszanych. Udział produkcji roślinnej wynosił od 32,8 do 70,7\%, podczas gdy w gospodarstwach ekologicznych od 45,1 do 65,2\% (tab. 3).

Najwyższy udział produkcji roślinnej w gospodarstwach mieszanych był w jednostkach ,średnio-dużych”, a w ekologicznych - w „,bardzo dużych”. Produkcja zwierzęca dominowała w gospodarstwach mieszanych „małych” i „,bar- 
dzo dużych" (66,4 i 56,9\%). W obydwu tych grupach największe znaczenie miała produkcja jaj (38,1 i 27,5\% wartości produkcji ogółem) i mleka krowiego (prawie po 13\%), natomiast w gospodarstwach ekologicznych głównie produkcja mleka krowiego i żywca wołowego. W gospodarstwach do 20 ha UR większy udział w produkcji ogółem miało mleko (23-24\%), a w gospodarstwach od 20 do 50 ha żywiec wołowy (około 20-23\%) - tabela 3.

W strukturze produkcji roślinnej gospodarstw mieszanych „małych” i ,średnio-małych" najwięcej znaczyły owoce, w gospodarstwach „średnio-dużych” warzywa, a w „bardzo dużych” zboża. Interesujące jest, że w gospodarstwach mieszanych „bardzo dużych”, w których udział sadów w UR, a także ich powierzchnia były większe niż w gospodarstwach ekologicznych $\mathrm{z}$ tego przedziału, produkcja owoców stanowiła zaledwie ułamek procenta, podczas gdy w ekologicznych aż 27,4\% wartości produkcji ogółem. W gospodarstwach ekologicznych mniejszych obszarowo (do $20 \mathrm{ha}$ ) w produkcji roślinnej dominowały warzywa i owoce. Łącznie stanowiły w produkcji ogółem około 26-30\%. Ich udział zmniejszył się do około 10-12\% w gospodarstwach od 20 do 50 ha UR, w których z kolei największy udział miały zboża (około 17-20\% wartości produkcji ogółem). Uwagę zwraca wysoki udział owoców $(27,4 \%)$ w produkcji gospodarstw ekologicznych największych obszarowo (powyżej 50 ha) - tab. 3 .

$\mathrm{Z}$ danych tabeli 1 wynika, że gospodarstwa ekologiczne i mieszane w trzech najmniejszych przedziałach obszarowych miały podobną powierzchnię użytków rolnych. Jednak realizowany program produkcji pozwolił na osiągnięcie podobnej wartości produkcji (około 55 tys. zł) tylko w gospodarstwach ,średnio-małych". W pozostałych grupach produkcja ogółem była wyższa w gospodarstwach mieszanych nawet około 2-krotnie (,średnio-duże" i "bardzo duże"). Odzwierciedleniem tych wyników była na ogół wyższa efektywność produkcji w gospodarstwach mieszanych. W tabeli 4 zaprezentowano produktywność czynników produkcji, wydajność techniczną produkcji pszenicy i mleka krowiego, a także efektywność kosztów w odniesieniu do 1 ha produkcji.

We wszystkich grupach obszarowych gospodarstw mieszanych produkcja była opłacalna, biorąc pod uwagę uzyskaną nadwyżkę produkcji nad poniesionymi kosztami. Natomiast spośród gospodarstw ekologicznych znaczna część badanej populacji $(32,2 \%)$ poniosła straty - tyczyło się to jednostek od 20 do 50 ha UR (,średnio-dużych” i „dużych”). Wynikało to z niskiej produktywności zarówno roślin, jak i zwierząt - wartość produkcji roślinnej na 1 ha równała się odpowiednio 1039 i 802 zł, a zwierzęcej 2392 i 2325 z/LU. Jedną z przyczyn tak słabych wyników były zapewne bardzo niskie koszty środków plonotwórczych, a w rezultacie niska wydajność techniczna produkcji, na co wskazuje choćby plon pszenicy i wydajność mleczna krów (tabela 4). Ponadto w gospodarstwach ekologicznych ,dużych” praktycznie nie było zbiorów z sadów, które zajmowały 4,6\% powierzchni UR (około 2 ha), a produkcja owoców na 1 ha uprawy wynosiła tylko 244 zł. Być może sady nie były w okresie owocowania? Podobna sytuacja miała miejsce w gospodarstwach mieszanych „bardzo dużych”, w któ- 
rych sady stanowiły 4,6\% w UR (6,3 ha), a wartość produkcji z 1 ha to zaledwie 329 zł. Trzeba natomiast zauważyć, że produkcja sadownicza była dość efektywna w gospodarstwach mniejszych obszarowo (do 30 ha), zarówno ekologicznych jak i mieszanych. Wyjątkowo wysoką produktywnością owoców cechowały się gospodarstwa ekologiczne „bardzo duże” (17 352 zł/ha).

Tabela 3

Poziom produkcji ogółem na gospodarstwo oraz udział procentowy ważniejszych składników

\begin{tabular}{|c|c|c|c|c|c|}
\hline \multirow{2}{*}{ Rodzaj gospodarstw } & Małe & Średnio-małe & Średnio-duże & Duże & \multirow{2}{*}{$\begin{array}{c}\text { Bardzo duże } \\
\text { ha }>50\end{array}$} \\
\hline & $5<\mathrm{ha} \leq 10$ & $10<\mathrm{ha} \leq 20$ & $20<\mathrm{ha} \leq 30$ & $30<\mathrm{ha} \leq 50$ & \\
\hline \multicolumn{6}{|c|}{ Udział produkcji roślinnej - \% } \\
\hline Mieszane & 32,8 & 55,5 & 70,7 & & 42,0 \\
\hline Ekologiczne & 48,5 & 51,1 & 46,5 & 45,1 & 65,2 \\
\hline \multicolumn{6}{|c|}{ w tym: } \\
\hline \multicolumn{6}{|c|}{ udział zbóż - \% } \\
\hline Mieszane & 5,5 & 18,0 & 13,6 & . & 26,6 \\
\hline Ekologiczne & 10,1 & 12,6 & 17,1 & 20,4 & 21,9 \\
\hline \multicolumn{6}{|c|}{ udział warzyw, truskawek - \% } \\
\hline Mieszane & 4,4 & 7,9 & 20,8 & & 0,2 \\
\hline Ekologiczne & 15,3 & 15,8 & 5,3 & 8,6 & 6,3 \\
\hline \multicolumn{6}{|c|}{ udział owoców - \% } \\
\hline Mieszane & 17,4 & 20,0 & 15,3 & & 0,4 \\
\hline Ekologiczne & 14,3 & 9,8 & 6,9 & 0,6 & 27,4 \\
\hline \multicolumn{6}{|c|}{ Udział produkcji zwierzęcej - \% } \\
\hline Mieszane & 66,4 & 43,9 & 26,6 & 3,9 & 56,9 \\
\hline Ekologiczne & 48,0 & 44,9 & 51,6 & 49,8 & 33,1 \\
\hline \multicolumn{6}{|c|}{ w tym: } \\
\hline \multicolumn{6}{|c|}{ udział mleka krowiego i jego przetworów - \% } \\
\hline Mieszane & 12,8 & 10,4 & 9,4 & . & 12,8 \\
\hline Ekologiczne & 23,2 & 24,0 & 17,3 & 9,9 & 15,2 \\
\hline \multicolumn{6}{|c|}{ udział żywca wołowego - \% } \\
\hline Mieszane & 8,5 & 18,1 & 10,6 & & 5,7 \\
\hline Ekologiczne & 13,5 & 11,0 & 22,6 & 19,7 & 9,6 \\
\hline \multicolumn{6}{|c|}{ udział żywca wieprzowego - \% } \\
\hline Mieszane & 4,4 & 5,8 & 4,7 & & 9,6 \\
\hline Ekologiczne & 5,9 & 3,0 & 4,0 & 3,5 & 2,6 \\
\hline \multicolumn{6}{|c|}{ udział produkcji jaj- $\%$} \\
\hline Mieszane & 38,1 & 7,0 & 0,6 & & 27,5 \\
\hline Ekologiczne & 4,2 & 2,2 & 4,7 & 3,6 & 5,4 \\
\hline
\end{tabular}

Źródło: Obliczenia na podstawie danych Polskiego FADN. 
Tabela 4

Efektywność gospodarowania w gospodarstwach mieszanych i ekologicznych

\begin{tabular}{|c|c|c|c|c|c|}
\hline \multirow{2}{*}{ Rodzaj gospodarstw } & Małe & Średnio-małe & Średnio-duże & Duże & Bardzo duże \\
\hline & $5<\mathrm{ha} \leq 10$ & $10<\mathrm{ha} \leq 20$ & $20<\mathrm{ha} \leq 30$ & $30<\mathrm{ha} \leq 50$ & ha $>50$ \\
\hline \multicolumn{6}{|c|}{ Produkcja ogółem - zł } \\
\hline Mieszane & 68537 & 55298 & 107367 & . & 469720 \\
\hline Ekologiczne & 40398 & 55665 & 54933 & 68415 & 202195 \\
\hline \multicolumn{6}{|c|}{ Koszty ogółem - zł } \\
\hline Mieszane & 48205 & 46872 & 90980 & . & 392754 \\
\hline Ekologiczne & 35886 & 48805 & 59380 & 79004 & 165463 \\
\hline \multicolumn{6}{|c|}{ Nadwyżka produkcji ogółem nad kosztami ogółem - zł } \\
\hline Mieszane & 20332 & 8427 & 16387 & . & 76966 \\
\hline Ekologiczne & 4512 & 6861 & -4447 & -10589 & 36732 \\
\hline \multicolumn{6}{|c|}{ Produkcja na 1 ha UR - zł } \\
\hline Mieszane & 9016 & 3689 & 4502 & . & 3418 \\
\hline Ekologiczne & 5206 & 3915 & 2191 & 1738 & 1934 \\
\hline \multicolumn{6}{|c|}{ Produkcja roślinna na 1 ha UR - zł } \\
\hline Mieszane & 3013 & 2071 & 3216 & . & 1485 \\
\hline Ekologiczne & 2583 & 2051 & 1039 & 802 & 1311 \\
\hline \multicolumn{6}{|c|}{ Produkcja zbóż na 1 ha ich uprawy - zł } \\
\hline Mieszane & 2096 & 1751 & 1911 & . & 2320 \\
\hline Ekologiczne & 1614 & 1669 & 1548 & 1178 & 1336 \\
\hline \multicolumn{6}{|c|}{ Produkcja warzyw i truskawek na 1 ha ich uprawy - zł } \\
\hline Mieszane & 21857 & 14959 & 21286 & . & 9576 \\
\hline Ekologiczne & 15917 & 14005 & 12618 & 18060 & 11780 \\
\hline \multicolumn{6}{|c|}{ Produkcja owoców na 1 ha ich uprawy - zł } \\
\hline Mieszane & 8218 & 6977 & 6420 & . & 329 \\
\hline Ekologiczne & 5965 & 6515 & 7763 & 244 & 17352 \\
\hline \multicolumn{6}{|c|}{ Produkcja zwierzęca na 1 LU - zł } \\
\hline Mieszane & 4169 & 2960 & 2932 & . & 4275 \\
\hline Ekologiczne & 3815 & 3395 & 2392 & 2325 & 3303 \\
\hline \multicolumn{6}{|c|}{ Produkcja na $1 \mathrm{AWU}-\mathrm{zł}$} \\
\hline Mieszane & 43334 & 31282 & 65160 & . & 207922 \\
\hline Ekologiczne & 21603 & 32976 & 22960 & 26321 & 75817 \\
\hline \multicolumn{6}{|c|}{ Plon pszenicy - dt/ha } \\
\hline Mieszane & 35,5 & 31,1 & 40,6 & . & 51,7 \\
\hline Ekologiczne & 28,4 & 30,7 & 33,3 & 20,0 & 29,1 \\
\hline \multicolumn{6}{|c|}{ Wydajność mleczna krów - kg/krowę } \\
\hline Mieszane & 2984 & 3165 & 3902 & . & 3615 \\
\hline Ekologiczne & 3580 & 3728 & 2997 & 3123 & 4746 \\
\hline
\end{tabular}

Źródło: Obliczenia na podstawie danych Polskiego FADN. 
Takich rozbieżności nie zanotowano w produktywności upraw warzywnych. Z wyjątkiem grupy „bardzo duże”, była ona wyższa w gospodarstwach mieszanych i wynosiła od 9576 zł do 21857 zł/ha warzyw, a w ekologicznych od 11780 zł do 18060 zł/ha. Gospodarstwa mieszane cechowały się też wyższą produktywnością zbóż niż ekologiczne, zwłaszcza w grupie największych obszarowo. Plon pszenicy wynosił tu $51,7 \mathrm{dt} / \mathrm{ha}$. Z wyjątkiem grupy gospodarstw ,średnio-małych”, również produkcja na 1 LU była wyższa w gospodarstwach mieszanych, a co istotne - najwyższa w gospodarstwach ,bardzo dużych" (4275 zł/LU), o 29\% wyższa niż w ekologicznych. Należy jednak zauważyć, że w większości grup wydajność mleczna krów była wyższa w gospodarstwach ekologicznych - tabela 4.

Duże zróżnicowanie poziomu produkcji w poszczególnych przedziałach obszarowych znalazło odzwierciedlenie w ekonomicznej wydajności pracy. W gospodarstwach ekologicznych, z wyjątkiem „bardzo dużych”, wynosiła ona od 21603 do 32976 zł/AWU. Tymczasem w gospodarstwach mieszanych najniższą jej wartość (31 282 zł/AWU) odnotowano w grupie jednostek ,średnio-małych”. W gospodarstwach ekologicznych największych obszarowo na jednostkę AWU przypadała produkcja o wartości $75817 \mathrm{zł}$, a w mieszanych niemal 3-krotnie wyższa (tabela 4).

Dochodowość gospodarstw. Wynik finansowy prowadzenia działalności operacyjnej w postaci dochodu $\mathrm{z}$ rodzinnego gospodarstwa rolnego (DzRGR) wskazuje ostatecznie na konkurencyjność ekonomiczną analizowanych gospodarstw mieszanych wobec ekologicznych.

Przewaga dochodowa gospodarstw mieszanych wzrosła po doliczeniu dopłat do działalności operacyjnej. Jak wskazują dane w tabeli 5, wielkość pozyskanych dopłat $\mathrm{w}$ przeliczeniu na 1 ha UR była niemal identyczna $\mathrm{w}$ gospodarstwach ekologicznych i mieszanych. Ostatecznie kwota DzRGR ukształtowała się na dość zbliżonym poziomie w gospodarstwach mieszanych „małych” i ,średnio-małych” (35 988 i 34718 zł), w ,średnio-dużych” wynosiła 62663 zł, a w ,bardzo dużych” 292383 zł. Przewaga dochodu w gospodarstwach mieszanych najmniejszych obszarowo w stosunku do gospodarstw ekologicznych wynosiła najwięcej - aż 77,4\%. Dochód w gospodarstwach ekologicznych „,małych" ukształtował się zaledwie na poziomie 20289 zł, a w największych obszarowo na poziomie 213829 zł. Dzięki wsparciu finansowemu gospodarstwa ekologiczne, które poniosły straty z produkcji (,średnio-duże” i „duże”), również osiągnęły dodatni wynik dochodowy, ale część dopłat pokryła koszty produkcji. W pozostałych grupach gospodarstw ekologicznych w 2013 roku dopłaty tworzyły dochód w około 81-84\% - tabela 5. Prowadzenie produkcji w analizowanych gospodarstwach ekologicznych byłoby niemożliwe bez wsparcia zewnętrznego, nie motywowałoby do jej kontynuowania w kolejnym roku. W gospodarstwach mieszanych dopłaty miały mniejszy udział w dochodzie, zwłaszcza w obiektach „małych” (46,4\%); w pozostałych wynosiły około 75-79\%. 
Tabela 5

Dochodowość i dopłaty w gospodarstwach mieszanych i ekologicznych

\begin{tabular}{cccccc}
\hline \multirow{2}{*}{ Rodzaj gospodarstw } & Małe & Średnio-małe & Średnio-duże & Duże & Bardzo duże \\
\cline { 2 - 6 } & $5<\mathrm{ha} \leq 10$ & $10<\mathrm{ha} \leq 20$ & $20<\mathrm{ha} \leq 30$ & $30<\mathrm{ha} \leq 50$ & $\mathrm{ha}>50$ \\
\hline
\end{tabular}

Dochód z rodzinnego gospodarstwa rolnego (DzRGR) - zł

\begin{tabular}{|c|c|c|c|c|c|}
\hline Mieszane & 35988 & 34718 & 62663 & . & 292383 \\
\hline Ekologiczne & 20289 & 34060 & 40551 & 58865 & 213829 \\
\hline \multicolumn{6}{|c|}{ Dopłaty do działalności operacyjnej - zł } \\
\hline Mieszane & 16682 & 27345 & 47028 & . & 219499 \\
\hline Ekologiczne & 16561 & 27692 & 47904 & 73759 & 179128 \\
\hline \multicolumn{6}{|c|}{ Dochód na 1 ha UR własnych - zł } \\
\hline Mieszane & 5601 & 2695 & 3280 & & 2808 \\
\hline Ekologiczne & 2882 & 2836 & 2037 & 1893 & 3218 \\
\hline \multicolumn{6}{|c|}{ Dopłaty na 1 ha UR - zł } \\
\hline Mieszane & 2195 & 1824 & 1972 & . & 1597 \\
\hline Ekologiczne & 2134 & 1948 & 1911 & 1874 & 1714 \\
\hline
\end{tabular}

Udział dopłat $\mathrm{w}$ dochodzie $\mathrm{z}$ rodzinnego gospodarstwa rolnego - \%

$\begin{array}{lrrrrr}\text { Mieszane } & 46,4 & 78,8 & 75,0 & . & 75,1 \\ \text { Ekologiczne } & 81,6 & 81,3 & 118,1 & 125,3 & 83,8\end{array}$

Relacja dopłat do produkcji - \%

$\begin{array}{llllrr}\text { Mieszane } & 24,3 & 49,4 & 43,8 & . & 46,7 \\ \text { Ekologiczne } & 41,0 & 49,7 & 87,2 & 107,8 & 88,6\end{array}$

Źródło: Obliczenia na podstawie danych Polskiego FADN.

Sytuacja dochodowa gospodarstw ekologicznych rysuje się jeszcze mniej korzystnie, jeśli wziąć pod uwagę dochody na osobę pełnozatrudnioną rodziny rolniczej (na FWU) - rysunek 4. W gospodarstwach do 30 ha UR (od „małych” do ,średnio-dużych”) dochód wynosił od 14153 do 26200 zł. Dopiero w grupie „dużych”, czyli o wielkości obszarowej od 30 do 50 ha przekroczył o około 7 tys. wartość średniego wynagrodzenia netto w gospodarce narodowej. Wśród gospodarstw mieszanych przekroczenie tego progu o około 11 tys. zł nastąpiło w jednostkach o mniejszym obszarze (od 20 do 30 ha). Poziom średniego wynagrodzenia netto kilkakrotnie przekroczyły gospodarstwa „,bardzo duże”, zarówno ekologiczne jak i mieszane. Z racji skali obszarowej były one też największymi beneficjentami dopłat. Dopływ dopłat spowodował, że w tych największych gospodarstwach ekologicznych dochód na 1 ha użytków rolnych własnych był wyższy od dochodu gospodarstw mieszanych o $15 \%$, choć produktywność ziemi tych ostatnich była wyższa o 77\% niż w ekologicznych. 


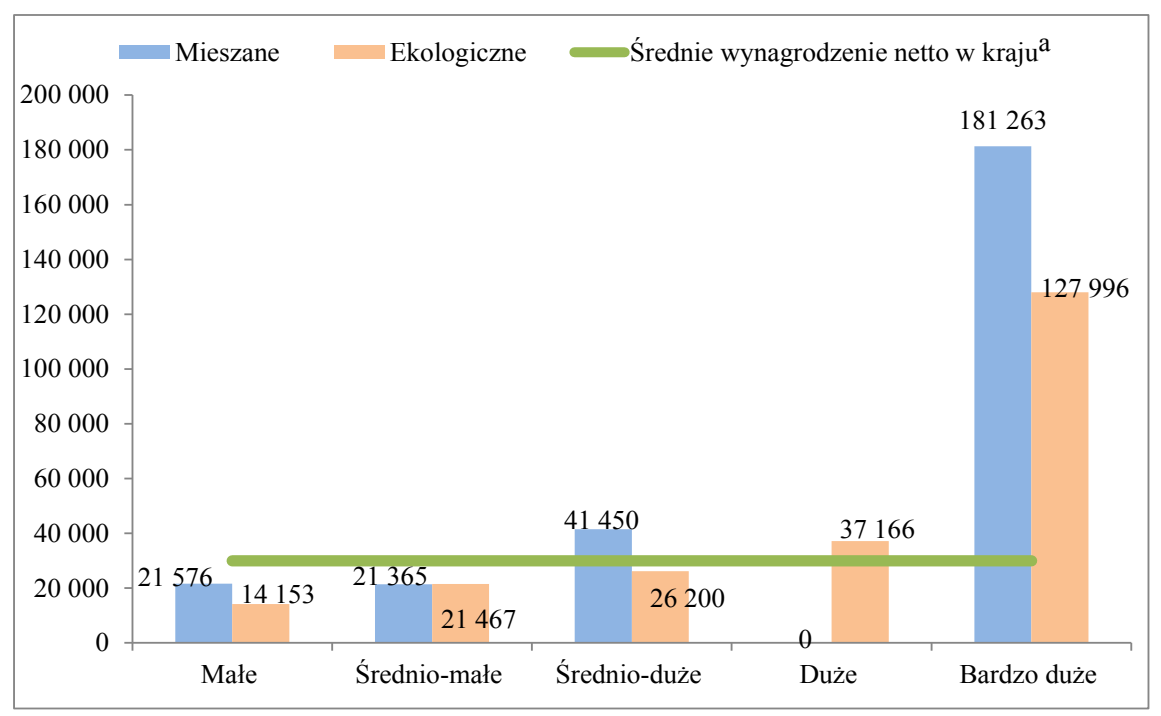

${ }^{\mathrm{a}}$ Średnie wynagrodzenie netto $\mathrm{w}$ kraju $=29953 \mathrm{zł}$.

Rys. 4. Dochód na osobę pełnozatrudnioną w rodzinie rolnika (FWU) w gospodarstwach mieszanych i ekologicznych - zł

Źródło: Obliczenie na podstawie danych Polskiego FADN.

\section{Podsumowanie}

W Polsce dopuszcza się współistnienie ekologicznego i konwencjonalnego systemu produkcji w jednym gospodarstwie. Takie mieszane jednostki w zestawieniach statystycznych są ujmowane jako gospodarstwa ekologiczne. Projekt nowelizacji Rozporządzenia 834/2007 w sprawie produkcji ekologicznej z 2014 roku zakłada wyłączenie takich mieszanych gospodarstw z sektora rolnictwa ekologicznego, bowiem doświadczenia minionych lat wskazują na trudności w kontroli takich jednostek, wątpliwości są też co do jakości produkcji ekologicznej. Ich stan ekonomiczny zaciera również prawdziwe oblicze ekonomiczne rolnictwa ekologicznego, utrudnia ocenę jego perspektyw rozwojowych.

$\mathrm{Z}$ analizy danych rachunkowych gospodarstw mieszanych znajdujących się w Polskim FADN wyraźnie widać ich konkurencyjność dochodową wobec gospodarstw ekologicznych w poszczególnych przedziałach obszarowych. Wynika to z faktu, że produkcja konwencjonalna jest korzystniejsza pod względem ekonomicznym niż ekologiczna. Gospodarstwa mieszane ponosiły z reguły wyższe koszty produkcji, ale ich skutkiem była wyższa efektywność produkcji. Wyraźne zastrzeżenia budzi jednak poziom produktywności upraw sadowniczych w gospodarstwach największych obszarowo, podobnie zresztą jak w przypadku gospodarstw ekologicznych „,dużych”. Gospodarstwa mieszane charakteryzowała na ogół wyższa obsada zwierząt na 1 ha, co wynikało ra- 
czej z ich chowu w systemie konwencjonalnym, a nie ekologicznym, zwłaszcza w przypadku ziarnożernych. Podobieństwo łączyło gospodarstwa mieszane i ekologiczne pod względem dopłat do działalności operacyjnej - ich poziom na 1 ha był bardzo zbliżony. Nie były one jednak warunkiem przetrwania gospodarstw mieszanych, tak jak w przypadku większości gospodarstw ekologicznych, w których udział dopłat w dochodzie wynosił od 81,3 do 125,3\%. Dopłaty rekompensowały niską produktywność ziemi w gospodarstwach ekologicznych, zwłaszcza w jednostkach powyżej 20 ha powierzchni. Nasuwa się przypuszczenie o niskiej jakości użytkowanych gleb w tych gospodarstwach, co należałoby zweryfikować w dalszych badaniach.

Różnice w wynikach finansowych analizowanych gospodarstw mieszanych i ekologicznych wskazują, że zakaz łączenia systemu ekologicznego i konwencjonalnego może zniechęcać rolników w przyszłości do podejmowania się produkcji ekologicznej, a także prowadzić do rezygnacji z produkcji ekologicznej tych, którzy obecnie realizują ją w części gospodarstwa.

\section{Literatura:}

1. Brodzińska K.: Kierunki i perspektywy rozwoju programu rolnośrodowiskowego w Polsce po 2013 roku. Woda-Środowisko-Obszary Wiejskie, t. 9 z. 3 (27). Instytut Melioracji i Użytków Zielonych w Falentach, 2009, s. 5-18.

2. Brodzińska K.: Rolnictwo ekologiczne - tendencje i kierunki zmian. Zeszyty Naukowe Szkoły Głównej Gospodarstwa Wiejskiego w Warszawie. Problemy Rolnictwa Światowego, t. 14 (XXIX), z. 3, 27-36. Wydawnictwo SGGW 2014.

3. Floriańczyk Z., Buks J.: Kwestie produktywności a strategie rozwoju polskiego sektora rolnego. Journal of Agribusiness and Rural Development 3(25) 2012, s. 101-112.

4. Floriańczyk Z., Mańko S., Osuch D., Płonka R.: Wyniki Standardowe 2013 uzyskane przez gospodarstwa rolne uczestniczące w Polskim FADN. Część II. Analiza Wyników Standardowych, Warszawa 2015, s. 20.

5. Jasiński J., Michalska S., Śpiewak R.: Rolnictwo ekologiczne jako czynnik rozwoju lokalnego. Wieś i Rolnictwo, nr 4 (165), Instytut Rozwoju Wsi i Rolnictwa Polska Akademia Nauk, 2014, s. 145-159.

6. Kuś J.: Rolnictwo ekologiczne i perspektywy jego rozwoju. Studia i Raporty IUNG-PIB, z. 26: 21-35, 2010.

7. Nachtman G. : Dochodowość gospodarstw ekologicznych a wielkość użytków rolnych. Roczniki Ekonomii Rolnictwa i Rozwoju Obszarów Wiejskich, t. 100, z. 1, Warszawa 2013, s. 182-196. „Wieś Jutra” Sp. z o.o.

8. Nachtman G.: Konkurencyjność ekologicznych gospodarstw roślinnych na tle gospodarstw prowadzących produkcję z udziałem zwierząt. Zagadnienia Ekonomiki Rolnej, nr 4, 2014, s. 131-143.

9. Nachtman G., Puchalska M.: Wyniki Standardowe 2013 uzyskane przez ekologiczne gospodarstwa rolne uczestniczące w Polskim FADN. Część II. Analiza Wyników Standardowych, Warszawa 2015. 
10. Program Rozwoju Obszarów Wiejskich na lata 2014-2020. Warszawa, 12 grudnia 2014 r.

11. Rozporządzenie Rady (WE) nr 834/2007 z dnia 28 czerwca 2007 r. w sprawie produkcji ekologicznej i znakowania produktów ekologicznych (Dz.Urz. UE L 189 z 20.07.2007, z późn. zm.).

12. Wniosek ROZPORZĄDZENIE PARLAMENTU EUROPEJSKIEGO I RADY w sprawie produkcji ekologicznej i znakowania produktów ekologicznych, zmieniające rozporządzenie Parlamentu Europejskiego i Rady (UE) nr XXX/XXX [rozporządzenie o kontrolach urzędowych] i uchylające rozporządzenie Rady (WE) nr 834/2007. Bruksela, dnia 24.3.2014 r.

GRAŻYNA NACHTMAN

Institute of Agricultural and Food Economics

- National Research Institute

Warsaw

\title{
FARMS COMBINING ORGANIC AND CONVENTIONAL PRODUCTION METHODS AT THE BACKGROUND OF ORGANIC FARMS
}

\begin{abstract}
Summary
Organic farming in Poland covers farms using only organic farming methods and farms where organic and conventional systems coexist. Statistics capture them jointly as organic farms.

This distorts the real picture of the Polish organic farming, especially the average area of farms, and production and economic situation, which is evidenced by data from organic farms keeping accounting under the Polish FADN. There were considerable differences between the analysed organic and "mixed" farms as regards the cropping structure and livestock population, level of incurred costs and production efficiency, thereby their profitability. Results of the analysis proved that mixed farms were fairly competitive in economic terms against farms using strictly organic production methods, and their income was far less dependent on external support, although the level of subsidies to operating activities per 1 ha of utilised agricultural area was close to the level noted for organic farms.
\end{abstract}

Key words: organic farming, organic and conventional production system, agricultural accountancy, organic production efficiency, profitability of organic farms

Zaakceptowano do druku - Accepted for print: 28.08.2015. 